
\title{
25 Research Soure \\ Fibronectin and mutant p53 gene make for deadly duo in ovarian carcinomas
}

\author{
Ako Yokoi \\ Toshihide Matsumoto \\ Yasuko Oguri \\ Yoshinori Hasegawa \\ Masataka Tochimoto \\ Mayu Nakagawa \\ Makoto Saegusa
}

\section{Video Byte}

Keywords: Cell Communication and Signaling, Kitasato University School of Medicine, ovarian carcinoma, p53, HNF-1 $\beta$, ARID1A, fibronectin, prognosis, immunophenotype, cell proliferation, cell mobility, apoptosis, knockdown, epithelial-mesenchymal transition, cancer stem cell, next generation sequencing, cell motility, overall survival, progression-free survival, checkpoint

Posted Date: November 3rd, 2020

DOI: https://doi.org/10.21203/rs.3.rs-102120/v1

License: (c) (i) This work is licensed under a Creative Commons Attribution 4.0 International License. Read Full License 


\section{Abstract}

p53 is widely considered the most frequently mutated gene in human disease, including in cancer. Normally, p53 acts as a checkpoint for recognizing DNA damage and actually suppresses tumor formation. Alterations to $\mathrm{p} 53$ compromise this function and can make way for life-threatening tumor growth. A new study examined how abnormal p53 might create conditions favorable for one of the most aggressive forms of ovarian carcinoma. The authors of the study began by knocking the p53 gene out of ovarian carcinoma cells and monitoring the effects. Next-generation sequencing of the p53-less cells revealed significantly elevated expression of fibronectin, a structural protein linked to various carcinomas. Loss of p53 function also appeared to boost the cancer cells' ability to migrate and spread. Data on actual patients with ovarian cancer confirmed the pattern observed in the lab. A combination of high fibronectin and high p53 expression was linked to the worst rates of overall survival and progression-free survival in patients. The findings suggest that testing for fibronectin and p53 expression could be extremely valuable in predicting and treating ovarian carcinoma. 